\title{
ERROR ANALYSIS MADE BY EFL LEARNERS IN WRITING PRONOUN (ACADEMIC YEAR 2015) AT ENGLISH DEPARTMENT AT FKIP UHN PEMATANGSIANTAR
}

\author{
Reina Adelina Sipahutar \\ Eben Pasaribu \\ FKIP Universitas HKBP Nommensen Pematangsiantar \\ reinasipahutar@yahoo.com
}

\begin{abstract}
This research is about Error Analysis Made By EfL Learners In Writing Pronoun (Academic Year 2015) At English Department At Fkip Uhn Pematangsiantar.. Error are any deviation from the standard grammar of the target language, while the personal pronoun is reffering to a person or thing. This research focused on the problem about (1) What types of errors produced by English learners in using Pronoun on the fourth semester in FKIP UHN Pematangsiantar? (2) What are the percentage of errors produced by English learners in using pronoun on the fourth semester in FKIP UHN Pematangsiantar? (3) What are the causes of errors produced by English learners in using Pronoun on the fourth semester in FKIP UHN Pematangsiantar? To answer the question of the problem, the writer follows some theories House and Harman (1931), Curme (1947), Meade et al. (1964), Harris (1969), Frank (1972), Corder (1973), Brown (1980), Abbot (1981), Brown (2000), Pyle and Munoz (2002), Arikunto (2006) to analyzed the data. The learners are sitting in the class of Language Metafunction in 2017 (Academic Year 2015). The writers will choose 20 students from each of the three classes (Group A, B, and C). The total numbers of the subject is 60 EFL learners.The data Shows that. The writer finds out that the Error of Addition (29 errors or 6,15\%), Error of Omission (175 or 371\%), Error of Substitution (225 error or 47,77\%) and Error of Ordering (42 error or 8,91\%). The dominant type of error was substitution errors (225 error or 47,77\%). The mean is 16,54 and standard deviation is 7,17. The test is valid where the validity is 0.55 .The test is also reliable where the reliability is 0.88 . The average of the right score is 17 items out of 30 items and the percentage is 55,14\%. The average of the wrong score (error score) is 13 items out of 30 items and the percentage is 44,85\%. Finally the writer suggests to the English teachers to have a good teaching strategy to explain the use of personal pronoun.
\end{abstract}

Keywords: error, personal pronoun, teaching

\begin{abstract}
ABSTRAK
Penelitian ini adalah tentang Analisis kesalahan yang dilakukan oleh mahasiswa yang belajar bahasa Inggris sebagai Bahasa Asing) Program Studi Pendidikan Bahasa Inggris FKIP UHN Pematangsiantar. Kesalahan merupakan segala yang tidak baku dari tata bahasa yang standar sesuai dengan target bahasa, sementara kata ganti diartikan untuk orang atau benda. Penelitian ini difokuskan terhadap masalah tentang: (1) Apakah tipetipe dari kesalahan yang dihasilkan oleh mahasiswa jurusan Bahasa Inggris dalam menggunakan kata ganti pada semester IV di FKIP UHN Pematangsiantar? (2) Apakah persentase dari kesalahan dihasilkan oleh oleh mahasiswa jurusan Bahasa Inggris dalam menggunakan kata ganti pada semester IV di FKIP UHN Pematangsiantar? (3) Apakah penyebab kesalahan dihasilkan oleh oleh mahasiswa jurusan Bahasa Inggris dalam menggunakan kata ganti pada semester IV di FKIP UHN Pematangsiantar? Untuk menjawab pertanyaan di atas, penulis mengikuti teori House dan Harman (1931), Curme (1947), Meade dkk (1964), Harris (1969), Frank (1972), Corder (1973), Brown (1980), Abbot (1981), Brown (2000), Pyle dan Munoz (2002), Arikunto (2006) untuk menganalisis data. Mahasiswa duduk di kelas mata kuliah Language Metafunction tahun 2017 (Tahun Akademik 2015). Penulis memilih 20 mahasiswa dari tiga kelas (Grup A, B, dan C). Total jumlah subjek penelitian adalah 60 mahasiswa yang belajar Bahasa Inggris sebagai bahasa asing. Data menunjukkan bahwa penulis menemukan kesalahan penambahan (29 kesalahan atau 6,15\%), kesalahan pengurangan (175 atau 371\%), kesalahan dalam pergantian (225 kesalahan atau 47,77\%) dan kesalahan ordering (42 kesalahan atau 8,91\%). Tipe yang paling dominan adalah kesalahan mengganti (225 kesalahan atau 47,77\%). Nilai rata-rata 16,54 dan simpangan baku adalah 7,17. Uji tesnya sah dengan mencapai 0.55 . Tes-nya juga terbukti terpercaya dikarenakan nilai reliabilitas adalah 0,88 . Jumlah skor yang salah yaitu 13 butir dari 30 butir dan persentasenya adalah 44,85\%. Pada akhirnya penulis menyarankan guru Bahasa Inggris menggunakan strategi mengajar yang baik saat membahas mengenai kata ganti personal.
\end{abstract}

Kata Kunci: kesalahan, kata ganti, pengajaran 


\section{INTRODUCTION}

\section{Background of the Study}

A mistake refers to a performance error that is a failure to utilize a known system correctly. Error may occur in all components of language such as grammar. Knapp (2005, p. 33 ) says that grammar therefore needs to deal with language from three perspectives: the generic, the textual, and syntactical. Error is a systematic deviation from the accepted system of target language. Mistake is a non systematic deviation from accepted system of the target language. While lapse is a non systematic deviation from the accepted system of language being learnt it's usually due to human limitation such as tiredness, nervous, and fatigue. Frank (1972, p. 21) divided Pronoun into seven types, namely:

1) Personal pronoun is a direct substitute for a noun. In other words, personal pronoun is a pronoun is a pronoun referring to a person or thing.

2) Interrogative pronoun introduce direct and indirect question.

3) Relative Pronoun refers to noun antecedents that immediately precede them. They introduce adjective clauses in which they serve as subject or object.

4) Demonstrative pronoun point out someone or something. The most common demonstrative pronouns are this (plural these), and that (plural those).

5) Reflexive pronoun is a combination of self with one of personal pronouns or with the impersonal pronouns one.

6) Reciprocal pronoun has the same identity as the subject, like the reflexive pronoun. The reciprocal pronoun indicates that the individual members of a plural subject mutually react one on the other.

7) Indefinite pronoun refers to indefinite (usually unknown) person or things to indefinite quantities. Indefinite person or things: someone, somebody, something, anybody, anyone, anything, nobody, no one, nothing, everyone, everybody, everything. Indefinite quantities: all, another, both, each, either, few, least, less, little, etc.

However seven types of pronoun pointed out important formal differences: many pronouns are more highly implicated for grammatical properties, I,e : person, number, case, and gender. All pronouns lack of the derivational ending such as: -ion, ment, - etc that noun have (Frank, 1972, p. 20). Among the various kinds of pronoun, the subject is focus only in using personal pronoun as function and position as subject and object. A personal pronoun is a special type of pronoun and a direct substitute for a noun. In order words, personal pronoun is a pronoun referring to person or thin (Meade et al., 1961, p. 205). Personal pronoun may be looked upon as a noun phrase of the simplest possible structure, which a rule, allow neither pre modification nor post modification. In addition, Personal pronouns have morphological characteristics. A personal pronoun changes form to indicate person, number, gender, case (Meade et al., 1964, p. 80). Personal pronouns are marked for Person contrast between $1^{\text {st }}, 2^{\text {st }}, 3^{\text {st }}$ person. Pronouns used by the person speaking to refer to himself are called first person pronouns. Pronouns used to mean the person to whom he is speaking are called second person pronoun. Pronoun referring to another person about whom statement are made are called third person pronouns. For Number: Singular and Plural. For Gender is over grammatical contrast between masculine, feminine and neutral gender and for Case, there is a contrast between subject pronoun and object pronoun.

Errors are those features of learner's utterances that are different from those of any native speaker and the learners do not recognize this error, so they cannot correct the error by themselves (Corder, 1973, p. 260). Error also is the use of linguistic items (example: word, grammatical, speech act, etc) in a way which a fluent or native speaker of the language regards as showing faulty or incomplete learning. students often make errors because of a misleading explanation from the teacher, faulty presentation of a structure or word in a textbook, or even because of a pattern that was rootle memorized in a drill but improperly contextualized and also caused error from language transfer (first language interference) that is the errors produced by the students caused by borrowing the pattern from mother tongue. In order to analyze learner language in appropriate perspective, it is crucial to make a distinction between mistake and error. 
Corder (1973, p. 85) said that the learners who do not understand language system cause error. Mistake causes the learner cannot use expression word to correct the grammar. In mistake, the learners have known language system that used, but because certain case the learners forgot the language system.

\section{Research Questions}

Based on the explanation above, the writer interested to analyses it and have purpose at this study at identify the errors made by students in using personal pronoun. Because the writers want to find out, what types of errors produced by English learners in using Pronoun on the fourth semester in FKIP UHN Pematangsiantar? The problems of this research proposal are formulated as follows:

1) What types of errors produced by English learners in using Pronoun on the fourth semester in FKIP UHN Pematangsiantar?

2) What are the Percentage of errors produced by English learners in using Pronoun on the fourth semester in FKIP UHN Pematangsiantar?

3) What are the causes of errors produced by English learners in using Pronoun on the fourth semester in FKIP UHN Pematangsiantar?

\section{Objectives of the Study}

The writer would like to analyze the errors on English Learners' Writing taken from the class Language Metafunction (Grup A, B, and C). According to Brown (2000, p. 169), there are four types of errors, they are: Error of Ommission, Error of Addition, Misformation, and Misordering.

\section{LITERATURE REVIEW}

\section{Error}

Errors are a result of partial knowledge because the teaching- learning process extends overtime. Language, as we have seen is a self- contained system, all part being interconnected a system of systems (Corder, 1973, p. 283). It is generally maintained, and the writer has assumed it up to now that errors show sign of the influence of the mother tongue or other language possessed by the learner. It is then quite reasonable to say that errors are unavoidable in terms on mastering the foreign language. The differences of mother tongue and the target language will add up the burden of learning. The learner or students sometimes pay little attention to the occurrence of errors in their speech or writing. The assume that it is the job of the teacher to tell them the errors which should be eliminated.

\section{Types of Error}

According to Corder (1973, p. 277), errors can be classified into four types, they are:

1) Error of Addition: occur where some element are presented which should not be there

2) Error of Omission : occur where some elements are omitted they should be presented

3) Error of substitution or selection: occur where the wrong item has been chosen in the place of the right one

4) Ordering: occur where the element presented are correct but incorrect sequence.

To identify the errors in second language learner, the step in the analysis of erroneous learner is that of determining the source of error. Brown $(2000$, p. 223) noted that the sources of the error could be divided into categories such as:

1) Interlingual Error: Interlingual transfer is a significant source of error for all learners. The beginning stage of learning a second language is especially vulnerable to interlingual transfer from the native language or interferences. In these early stages, before the system of the second language is familiar, the native language is the only previous linguistic system upon which the learners can draw. Example: I am bearing on 04 December 1994. The learner used the wrong tenses and incorrect in used of word. It is because the learner transfer from the native language. It should be: I was born in 4 December 1994 (Brown, 2000, p. 224).

2) Intralingual Transfer: (within the target language itself) is a major factor in second language learning (Brown, 2000, p. 224). 
3) Context of learning: A third major source of error, although it overlaps both types of transfer, is the context of learning. "Context" refers, for example, to the classroom with its teacher and its material in the case of school learning or the social situation in the case of untutored second language learning. Students often make errors because of a misleading explanation from the teacher, faulty presentation of a structure or word in a textbook, or even because of a pattern that was rootless memorized in a drill but improperly contextualized.

4) Communication Strategies: According to Brown (2000, p. 227), Communication strategies were defined and related to learning style. Learners obviously use production strategies in order to enhance getting their message across, but at time, these techniques can themselves become a source of error. For example: "let us work for the well done of our country". While it exhibited a nice little twist of a humor, the sentences had an incorrect approximation of the word welfare. Likewise, word coinage, circumlocution, false cognates and fabricated patterns can all be sources of error.

\section{Error Analysis}

Error analysis is the study and analysis of the error made by second foreign language students and intended to predict the error on the difficulties in learning a new language. According to Brown (2000, p. 218 ), error analysis is errors which are made by the students and that these errors can be observed, analyzed and classified to reveal something of the system operating within the learner to a surge of study of learners' error. Error analysis became distinguished from contrastive analysis by its examination of errors attribution to all possible sources, not just those that result from negative transfer of the native language. Error analysis easily superseded contrastive analysis, as we discovered that only some of the errors a learner makes are attribution to the mother tongue. Error analysis is an attempt to study learners' error (Crystal, 1978, p. 32). The application of linguistic and psychological theories to the study of foreign language teaching gives a new addition to discussion of error. Differences between two language and Interlingual become the sources of the student's error. Being aware of the differences between two languages and Interlinguals are very important for teachers and learners in teaching learning process.

Corder (1981, p. 45) concluded that error analysis has two functions, those are theoretical and practical aspect. Theoretical aspect of error analysis is part of the method used in investigating of the language of the language learning process. It means that if we want to find out the nature of these psychological that learner ought to have means of describing the students' knowledge of target language of any particular moment in his/her learning career in order to relate this knowledge the teaching that she/her has been receiving. The practical aspect of error analysis is its function in guiding the action that we must correct a non-static factory state of affairs for student or teacher.

\section{Procedures of Error Analysis}

According to Brown (1980, p. 167) there are steps in the procedures of analysis, they are:

1) Identifying the error

Corder in Brown (1980, p. 167) provided a model for identifying erroneous or idiosyncratic utterance in a second language. According to Corder's model, any sentences uttered by the learner and subsequently transcribed can be analyzed for idiosyncrasies. A major distinction is made at the outset between overt and covert errors. Overtly erroneous utterances are those that are unquestionably: covertly erroneous utterances are grammatically well formed but not interpretable within the formal context of communication. If the native language of the learner is known, the model indicates using translation as a possible indicator of native language interference a source of error. In some cases, of course, no plausible interpretation is possible at all, and the researcher is left with no analysis of the error. However, once an error is identified, the next step is to describe it adequately.

2) Describing Error

Brown (1980, p. 169) says "On a rather global level, error can be described as errors of addition, errors of omission, error of substitution and error of 
ordering". The second classification can be done according to the levels of language: phonology or orthography, lexicon, grammar, and discourse. The third classification can be considered from the systematically of the errors: presystematic errors, systematic errors, and post systematic errors. A pre-systematic error is a stage in which the learner is only vaguely aware that there is some systematic order to a particular class of items. When the learner has progressed to a systematic stage in a particular area of language, he began to discern a system, to be more consistent in this patterning, to exhibit rather consistent errors indicating internalization of rules, albeit "incorrect" rules by native speaker standard. A systematic error in Corder's conceptualization of the term, usually cannot be corrected by the learner, but he can 'explain' his error in this sense of providing, in different wording or structures. Post- systematic error is stage of learning is found when the learner is quite consistent in his speech, when he makes an error.

\section{Pronouns}

Pronouns as one part of speech are used to replace a noun or noun phrase. According to Meade et al. (1962, p. 206), pronoun is a word that stands for a noun. The traditional definition is pronoun as a word that takes of noun is applicable to some types of pronoun but no to others. The pronouns that are not substituted may simple have indefinite references or express indefinite quantity.Frank (1972, p. 20) assert that the modern grammarians who regard position and function of pronouns as the decisive factors are classifying parts of speech often considered pronouns as subclasses of noun. However, they pointed out important formal differences: many pronouns are more highly implicated for grammatical properties, such as person, number, case, and gender. All pronouns lack of the derivational ending such as -ion, -ment, -etc that noun have.

Frank (1972, p. 21) classified pronouns into seven types, namely: personal pronoun, relative pronoun, demonstrative pronoun, reflexive pronoun, reciprocal pronoun, indefinite pronoun, interrogative pronoun. Whatever meanings they have are derived from the context in which they are used. In addition, many pronouns have the ability to serve of two functions-they may stand alone in noun function, or they may act as adjectives (determiners) that precede descriptive adjectives.

\section{Personal Pronouns}

Personal pronoun is a direct substitute for a noun. In other words, personal pronoun is a pronoun referring to a person or thing (Frank, 1972, p. 21). A personal pronoun changes forms to indicate person, number, gender, and case (Meade et al., 1964, p. 80).

\section{Interrogative Pronouns}

Interrogative pronoun introduce direct or indirect question (Frank, 1972, p. 21). There are three interrogative pronounsWHO (for person), WHAT (for things), and which (for a choice involving either person or things). The pronoun WHAT also introduce exclamations, for example: What beautiful flowers those are. WHAT A is used with a singular countable noun, example: What a beautiful flower that is.

\section{Relative Pronoun}

Relative pronouns refer to noun antecedents, which immediately precede them. They introduce adjective clauses in which they serve as subject or object. The most common relative pronouns are WHO (for person), THAT (for person and things), WHICH (for things). AS sometimes also serve as a relative pronoun, for example: She likes the same things as (= that) her husband does (Frank, 1972, p. 21).

\section{Demonstrative Pronouns}

Frank (1972, p. 21) says, "Demonstrative pronouns point out someone or something. The most common demonstrative pronouns are THIS (plural these) and THAT (plural those)."

\section{Reflexive Pronouns}

The reflexive pronoun is a combination of -self with one of the personal pronoun or with the impersonal pronoun one (MYSELF, YOURSELF, HIMSELF, HERSELF, ITSELF, OURSELVES, YOURSELVES, And THEMSELVES). The reflexive pronoun generally refers to an animate being, usually a person. The most common use of the reflexive pronoun is as an 
object that" reflects back" to the subject in other words, it has the same identity as the subject (Frank, 1972, p. 22).

\section{Reciprocal Pronouns}

Like the reflexive pronouns, the reciprocal pronoun has the same identity as the subject. The reciprocal pronoun indicates that the individual members of a plural subject mutually react one on the other. The reciprocal pronouns are EACH OTHER and ONE ANOTHER. The schoolbook rule that each other should be used for two person and one another for three or more is not always observed by educated speakers (Frank, 1972, p. 22).

\section{Indefinite Pronouns}

Such pronouns refer to indefinite (usually unknown) person or things, or to indefinite quantities (Frank 1972, p. 23). Indefinite person or things, these pronouns are all-singular in form and are used without noun antecedents. They consist of the following compounds: Some $=$ SOMEBODY, SOMEONE, SOMETHING, any= ANYBODY, ANYONE, ANYTHING

The forms with no- generally make a sentence negative rather than the forms with any- or every- plus a negative verb.Indefinite quantities such as ALL, ANOTHER, ANY, BOTH, EACH, EITHER, FEW, LEAST, LESS, LITTLE, A LOT (OF), MANY, MORE, MOST, MUCH, NEITHER, NONE, ONE, OTHER(S), PLENTY (OF), SEVERAL, SOME (Frank, 1972, p. 23). Many grammarians also include the numeral (one, first, etc) among the indefinite pronouns. Although the numerals refer to definite quantities, they resemble indefinite pronouns in many ways; especially in their ability to function as adjective that precede descriptive adjectives.

\section{RESEARCH METHOD}

\section{Research Design}

This research is Error Analysis on Students' Writing Among EFL Learners on the Fourth Semester at FKIP UHN Pematangsiantar. The design of this research will be based on descriptive qualitative. It means that this study deals with one variable namely an analysis on the students' error in personal pronoun. The main reason to choose the descriptive quantitative design is because it is not only for collecting data, but furthermore to analyze the students' error in using personal pronoun.

\section{Subject of the Research}

The subject of this research is EFL Learners on the Fourth Semester at FKIP UHN Pematangsiantar. The learners are sitting in the class of Language Metafunction in 2017 (Academic Year 2015). The writers will choose 20 students from each of the three classes (Group A, B, and C). The total numbers of the subject is $60 \mathrm{EFL}$ learners.

\section{Object of the Research}

The object of the research is the errors data made by EFL learners on writing which will be taken from Language Metafunction class on the Fourth Semester at FKIP UHN Pematangsiantar.

\section{Data Collection Procedures}

Collecting data is observing the variable, which is going to be researched by interview method, test method, observation method, questioner method, and so forth (Arikunto, 2002, p. 113).The writers use as the test method to know whether the students have errors in using personal pronoun or not. The writers use the students and test as the instrument to get the data. The achievement test used in this research is an Essay test by asking the learners to write an Essay with the topic: "What Can I Contribute for my Country Indonesia?". The writer aks the learners to write an essay in the length of 200-300 words in English.

\section{Data Analysis Procedures}

After the writer gets all the students score from the test, they analyze data to find out the errors. Here, the writer will find out whether the students have errors in using personal pronoun or not.The errors are analyzed by using the following steps:

1) Identify the data and present the kinds of errors that make by the students and the causes of the error

2) Analyze the data based of error of addition,error of ommission, error of subtitution or selection and error of ordering

3) Find out the percentage of errors 
4) Analyze the causes of error based on inter-lingual transfer and intra-lingual transfer.

\section{FINDINGS AND DISCUSSION}

\section{Identifying and Classifying the Errors}

Having checked the students' answer sheet, it was important to find out the errors by identifying and classifying the errors, which were drawn in the table form of representative 35 students.

Table 1. The Distribution The Error

\begin{tabular}{|c|c|c|}
\hline No & Right & Error \\
\hline 1 & 18 & 12 \\
\hline 2 & 15 & 15 \\
\hline 3 & 17 & 13 \\
\hline 4 & 20 & 10 \\
\hline 5 & 10 & 20 \\
\hline 6 & 12 & 18 \\
\hline 7 & 17 & 13 \\
\hline 8 & 23 & 7 \\
\hline 9 & 23 & 7 \\
\hline 10 & 23 & 7 \\
\hline 11 & 14 & 16 \\
\hline 12 & 18 & 12 \\
\hline 13 & 8 & 22 \\
\hline 14 & 23 & 7 \\
\hline 15 & 20 & 10 \\
\hline 16 & 12 & 18 \\
\hline 17 & 20 & 10 \\
\hline 18 & 14 & 16 \\
\hline 19 & 21 & 9 \\
\hline 20 & 22 & 8 \\
\hline 21 & 21 & 9 \\
\hline 22 & 16 & 14 \\
\hline 23 & 20 & 10 \\
\hline 24 & 8 & 22 \\
\hline 25 & 17 & 13 \\
\hline 26 & 13 & 17 \\
\hline 27 & 20 & 10 \\
\hline 28 & 18 & 12 \\
\hline 29 & 6 & 24 \\
\hline 30 & 13 & 17 \\
\hline 31 & 15 & 15 \\
\hline 32 & 14 & 16 \\
\hline 33 & 13 & 17 \\
\hline 34 & 16 & 14 \\
\hline 35 & 19 & 11 \\
\hline Total & 579 & 471 \\
\hline
\end{tabular}

In Table 1, it can be seen the total errors of students in using personal pronoun. The total is 471 . It means that the students often made errors. Then the errors were classified into the types of error. After analyzing the data, there were 4 types of errors that made by students:

The table identification described that the students' error can be categorized into four types, addition, omission, substitution and ordering. When the errors were viewed from the types of errors, the most errors which made by the students was substitution errors. It was $47.77 \%$ or 225 errors, omission $371,15 \%$ or 175 errors. Ordering was $8,91 \%$ or 42 errors, and addition $6,15 \%$ or 29 errors.

\section{Research Findings}

Research finding is the conclusion of the research result by data shown, after making research, the writer found that: the students who find error of Addition (29 errors or 6,15\%), The students who find Error of Omission $(175 \%$ or $371 \%)$, the students who find error of Substitution (225 error or $47,77 \%$ ) and the students who find Error of Ordering (42 error or $8,91 \%$ ) and the percentage is $55,14 \%$.

\section{Discussion}

The purpose of this research is to know whether EFL learners on writing which will be taken from Language Metafunction class on the Fourth Semester at FKIP UHN Pematangsiantar have error in using personal pronoun. The writer had been given them the test about personal pronoun and had checked their answer. The writer had also made the data analysis, and from the analysis, the writer found that: items on the students' errors are 471 . The students who find error of Addition (29 errors or 6,15\%) for example: Teacher: "Attention please! All of you're should do homework." It should be : Teacher: "Attention please! All of you should do homework". The students who find Error of Omission $(175 \%$ or $371 \%)$ for example: The snake is dangerous. We must kill their. It should be: the snake is dangerous. We must kill it. The students who find error of Substitution (225 error or 47,77\%) for example: I read some books. Their were good. The students who find Error of Ordering (42 error or $8,91 \%$ ) for example: I and you are good friend. It should be: you and I are good friend. 


\section{CONCLUSIONS AND SUGGESTIONS}

\section{Conclusions}

After analyzing the data, some conclusions can be drawn as the following:

1. Items on the test are 30 items and samples of the research are 35 students. The students who make the right answer are 579 and make the error 471 .

2. There are four types of error made by students in using personal pronoun, namely: Error of Addition (29 errors or $6,15 \%)$, Error of Omission $(175 \%$ or $371 \%$ ), Error of Substitution (225 error or $47,77 \%$ ) and Error of Ordering (42 error or $8,91 \%)$.

3. The dominant type of error was substitution errors (225 error or $47,77 \%$ ) because their error in selecting the function and position of personal pronoun as subject and object.

\section{Suggestions}

In relation to conclusion above, some suggestion are recommended as the following:

1. English teachers should have a good teaching strategy to explain the use of personal pronoun.

2. English teachers are recommended explain and give some relevant examples the use of personal pronoun in English.

3. English teachers should give more exercises, quiz or games to the students in order that the students have a motivation in studying personal pronoun.

4. English teachers should improve their skills in teaching presentations.

5. The students should give more attention and learn much more about personal pronoun.

The students should give more attention to English teachers' explanation about personal pronoun to improve their knowledge.

\section{REFERENCES}

Abbot, G. (1981) The teaching of English as an international language. London: William Collin Sons and Ctol.

Arikunto, S. (2006) Prosedur penelitian: Suatu pendekatan praktik. Jakarta: Rineka Cipta.

Brown, H.D. (1980). Principles of language learning and teaching. New Jersey, $\mathrm{NJ}$ : Prentice Hall.

Brown, H.D. (1980). Principles of language learning and teaching. San Fransisco: Prentice Hall.

Corder, S.P. (1973). The study of language learner language error: An introduction to applied linguistics. London: Great Britain Penguin.

Curme, G. O. (1947). English grammar. New York, NY: Barnes and Noble.

Frank, M. (1972). Modern English: A practical reference guide. New Jersey, NJ: Prentice Hall.

Gay, L. (1978). Educational researches: Competence for analysis and application. Ohio: Merril.

House, H. C., \& Harman, S.E. (1931). Descriptive English grammar. Eaglewood: Prentice Hall.

Meade, R.A. et al. (1964). Effective English. Boston: Allyn and Bacon.

Pyle, H.A., \& Munoz, M.E. (2002). Cliffs test of English as a foreign language: Preparation guide. USA: John Wiley and Sons. 